\title{
Trophic state and its implications for natural reproduction of salmonid fish
}

\author{
Rudolf Müller \\ Swiss Federal Institute for Water Resources and Water Pollution Control (EAWAG), \\ CH-6047 Kastanienbaum, Switzerland
}

Key words: Salmonids, Coregonus, egg development, trophic state, lake restoration

\begin{abstract}
Natural propagation of all fish species native to a particular lake is an ecological requirement of prime importance. Salmonid fish are particularly vulnerable to environmental degradation since egg development takes place on or in the bottom substrate. Dissolved oxygen concentration on the spawning site is commonly considered the main factor limiting egg development. In order to assess the relationship between trophic state, hypolimnetic oxygen concentration, and salmonid egg development, whitefish (Coregonus sp.) eggs were sampled just prior to hatching in late winter. Eggs were collected in 13 Swiss lakes of different trophic state, using a sled-dredge. The proportion of viable eggs among the total number of eggs found was taken as a measure of reproductive success. The results indicate that successful in situ embryogenesis is not primarily governed by hypolimnetic oxygen concentration which tends to be high anyway during egg incubation, but by trophic state in terms of total phosphorus concentration in spring. The findings are explained by the production-related oxygen uptake of the sediment, creating an oxygen gradient of varying steepness in the diffusive boundary layer. Implications for the restoration of lacustrine ecosystems are discussed.
\end{abstract}

\section{Introduction}

Up to the end of the 19th Century, most Central European lakes were characterized by low nutrient content, low productivity, a modest fishing yield, and a fish community dominated by salmonid species such as whitefish (Coregonus sp.), and arctic charr (Salvelinus alpinus L.). With increasing eutrophication, particularly between 1940 and 1975 , environmental conditions for natural reproduction of salmonid fish deteriorated to a point where natural supply of progeny became negligible. In anticipation of this development, gradually intensified stocking with artificially hatched fry of whitefish and charr was practiced from the turn of the century on. In spite of these efforts, a number of endemic whitefish 'species' in Swiss lakes have died out (e.g. C. asperi Fatio in Lakes Greifensee and Pfäffikersee, $C$. suidteri Fatio in Lake Sempach; Steinmann, 1950). The mechanism responsible was thought to be oxygen depletion in the hypolimnion, leading to suffocation of the embryos developing on the lake bottom.

In the past decades, water pollution control, in particular phosphorus removal from sewage discharged into lakes or lake tributaries, has led to a significant decrease of phosphorus content in Swiss lakes (Ambühl, 1987). While oligotrophication of the formerly mesotrophic lakes has led to mean total phosphorus concentrations already 
well below $20 \mathrm{mg} \mathrm{m}^{-3}$, several lakes remain eutrophic, with more than $100 \mathrm{mg} \mathrm{m}^{-3}$ total phosphorus. The aim of lake restoration, based on the Swiss water quality standards, is to lower mean total phosphorus concentration to $30 \mathrm{mg} \mathrm{m}^{-3}$, corresponding to primary production of $150 \mathrm{~g} \mathrm{C} \mathrm{m}^{-2} \mathrm{y}^{-1}$, and to maintain an oxygen concentration of at least $4 \mathrm{mg} \mathrm{l}^{-1}$ at all times and throughout the lake (Gächter, 1987). From the point of view of fish ecology and fishery, the aims of lake restoration may be defined as follows:

1. Natural reproduction of all fish species occurring naturally must be functional

2. Inhabitable space must meet the requirements of fish, both qualitatively and quantitatively

3. Fish species composition should be typical of oligotrophic lakes

4. Moderate fishing yield should be guaranteed.

Environmental factors are known to greatly influence reproductive success of salmonids in lakes. However, the relationship between trophic state as a general environmental qualifier and egg development has rarely been investigated. Lahti (1979) found that vendace (Coregonus albula L.) egg mortality was low in oligotrophic lakes and high in dystrophic lakes in Finland. Whitefish egg mortality in mesotrophic and eutrophic Polish lakes was mainly related to the quality of the fertilized eggs and to the structure (mud and sand content) of the sediment (Wilkonska \& Zuromska, 1981). In the course of a research project on L. Sempach (Switzerland), it was found in 1988 that in spite of oxygen concentrations of more than $7 \mathrm{mg} \mathrm{1}^{-1}$ measured only a few centimeters above the sediment surface, all eggs died during embryogenesis in the lake (Ventling-Schwank \& Müller, 1990). The same was found in eutrophic L. Hallwil in early 1988. A survey conducted in 1989 revealed a similar situation in eutrophic Lake Zug, with oxygen concentration on the spawning grounds higher than $9 \mathrm{mg} \mathrm{l}^{-1}$. However, an investigation on whitefish reproduction in oligotrophic Lake Sarnen in 1982-1985 had indicated that $36.3-77.8 \%$ of the fertilized whitefish eggs just prior to hatching were viable. It was therefore concluded that hypolimnetic oxygen concentra- tion could not have been the cause of the impairment of embryogenesis in eutrophic lakes, and that some mechanism related to trophic state, such as sediment quality, must have been responsible for total egg mortality. In order to explore the extent and cause of this phenomenon, a survey of whitefish egg development in 12 Swiss lakes of varying trophic state was conducted in early 1990. The aim of this paper is thus to elucidate the relationship between trophic state and in situ whitefish embryogenesis, based mainly on the results of the 1990 survey, and to interpret the findings in view of the current objectives and practices of lake restoration.

\section{Material and methods}

\section{Sampling sites}

Morphometric characteristics of the lakes are summarized in Table 1 (for locations see Steinmann, 1950). Mean phosphorus concentration at spring overturn $\left(\mathrm{P}_{\text {tot }}\right.$ and $\left.\mathrm{PO}_{4}-\mathrm{P}\right)$ was used as a measure of trophic state (Vollenweider, 1968; Fricker, 1980). Phosphorus values refer to the year preceding egg sampling since this value controls primary production and sedimentation, and thus the quality of the sediment surface on which the eggs will develop (see below). Data on phosphorus concentration in spring, and on oxygen concentration during the egg incubation period (November to February) were obtained from the local water protection agencies. All lakes are stocked each year with large numbers of whitefish fry or juveniles in order to maintain fishable stocks.

\section{Egg sampling methods}

Whitefish eggs were collected on the lake bottom using a sled dredge (Elster, 1933, modified). The dredge is hauled by a boat and can be deployed at any depth by the aid of a winch. The dredge weighs $42 \mathrm{~kg}$ when empty, has a mouth width of $50 \mathrm{~cm}$ and a mesh aperture in the wire basket of 
Table 1. Morphometric characteristics of the lakes included in the study.

\begin{tabular}{|c|c|c|c|c|c|c|c|}
\hline \multirow[t]{2}{*}{ Lake } & \multirow[t]{2}{*}{$\begin{array}{l}\text { Surface } \\
\text { area } \\
\left(\mathrm{km}^{2}\right)\end{array}$} & \multirow[t]{2}{*}{$\begin{array}{l}\text { Maximum } \\
\text { depth } \\
\text { (m) }\end{array}$} & \multirow[t]{2}{*}{$\begin{array}{l}\text { Mean } \\
\text { depth } \\
\text { (m) }\end{array}$} & \multirow[t]{2}{*}{$\begin{array}{l}\text { Volume } \\
\left(\mathrm{km}^{3}\right)\end{array}$} & \multirow[t]{2}{*}{$\begin{array}{l}\text { Flushing } \\
\text { rate } \\
\left(y^{-1}\right)\end{array}$} & \multicolumn{2}{|c|}{$\begin{array}{l}\text { Average epilimnetic } \\
\text { phosphorus concentration } \\
\left(\mathrm{mg} \mathrm{m}^{-3}\right) \text { in spring } 1989\end{array}$} \\
\hline & & & & & & $\mathrm{PO}_{4}-\mathrm{P}$ & $P_{\text {tot }}$ \\
\hline L. Geneva & 582 & 305 & 153 & 89.1 & 0.084 & 37 & 47 \\
\hline Upper L. Constance & 476 & 252 & 100 & 47.6 & 0.233 & 36 & 42 \\
\hline Lower L. Constance & 63 & 46 & 28 & 1.76 & 12.5 & 26 & 34 \\
\hline L. Neuchâtel & 216 & 152 & 64 & 13.8 & 0.121 & 13 & 32 \\
\hline L. Lucerne & 114 & 214 & 104 & 11.8 & 0.294 & 3.2 & 9.7 \\
\hline Upper L. Zurich & 20.9 & 49 & 23 & 0.48 & 5.55 & 4 & 14 \\
\hline Lower L. Zurich & 67.5 & 136 & 49 & 3.3 & 0.909 & 6 & 24 \\
\hline L. Thun & 48.3 & 217 & 124 & 6.0 & 0.526 & 7 & 12 \\
\hline L. Biel & 39.3 & 75 & 31 & 1.22 & 6.25 & 13 & 38 \\
\hline L. Zug & 38.3 & 197 & 83 & 3.2 & 0.070 & 111 & 125 \\
\hline L. Walenstadt & 24.1 & 150 & 103 & 2.5 & 0.800 & 3 & 7 \\
\hline L. Sempach & 14.5 & 87 & 44 & 0.64 & 0.059 & 103 & 117 \\
\hline L. Hallwil & 10.3 & 47 & 28 & 0.29 & 0.263 & 92 & 111 \\
\hline L. Joux & 8.7 & 33.5 & 15.2 & 0.13 & 1.0 & $10^{*}$ & $20^{*}$ \\
\hline L. Sarnen & 7.6 & 52 & 33 & 0.25 & 1.25 & 1 & 6 \\
\hline
\end{tabular}

* in 1982 .

$1 \mathrm{~mm}$. In every lake sampled, four to seven hauls were made on locations known or assumed to be whitefish spawning grounds. Hauling speed was $0.5-0.7 \mathrm{~m} \mathrm{~s}^{-1}$, and hauling time $3-16 \mathrm{~min}$, depending on the quality of the lake bottom; on soft sediment the dredge filled with mud within 2$3 \mathrm{~min}$, while on sandy or stony bottoms, about one third of the basket was filled with debris within $15 \mathrm{~min}$. In Lake Thun, eggs of the shorespawning whitefish had to be collected by a diveroperated suction apparatus (Ventling-Schwank \& Müller, 1990), and by stirring up the gravel by hand and collecting the eggs with a fine-meshed dip net. The dredging samples were preserved in the field with $10 \%$ formaldehyde solution.

The proper timing of sampling eggs in a particular lake was chosen according to the spawning period of the specific whitefish stock, and by estimating the onset of hatching from lake water temperature and from the development of the whitefish eggs at the hatcheries on the lake shore. Egg sampling in 1990 started on 9th January in Lake Lucerne and ended on 7th March in Lake Neuchâtel.

At the laboratory, all eggs were sorted and classified according to one of the following criteria: (1) viable/normal, (2) viable/malformed embryo, (3) unfertilized, (4) dead/undeterminable, (5) empty with small hole (invertebrate predation; Nümann \& Quoss, 1972), (6) empty/split open (hatched). The criteria chosen for assessing the functioning of egg development was the percentage of viable, non-deformed embryos (almost ready to hatch, developmental stages 12-13; Luczynski \& Kirklewska, 1984) and empty shells from hatching among all possibly fertilized eggs found a few days before the anticipated beginning of mass hatching. The percentage of viable eggs was calculated as $(1)+(6) /(2)+(4)$. Since it is unlikely that all dead/undeterminable eggs were fertilized, the true proportion of viable eggs is underestimated. In Lakes Biel and Geneva, a small proportion of the embryos were considerably younger than developmental stages 12-13, i.e. stages 5 to 11 , probably due to extended spawning periods. In these cases, eggs from all stages were still categorized as above. The data set was completed by results from similar investigations on Upper Lake Constance and Lake Joux (see Table 2). 
Table 2. Results of whitefish egg sampling campaigns in 15 Swiss lakes.

\begin{tabular}{|c|c|c|c|c|c|}
\hline Lake & Year & $\begin{array}{l}\text { Sampling } \\
\text { depth }(\mathrm{m})\end{array}$ & $\begin{array}{l}\text { Number } \\
\text { of dredge } \\
\text { hauls }\end{array}$ & $\begin{array}{l}\text { Total nr. of } \\
\text { whitefish } \\
\text { eggs found }\end{array}$ & $\begin{array}{l}\text { Source } \\
\text { other than } \\
\text { this study }\end{array}$ \\
\hline L. Geneva & 1990 & $3.5-30$ & 7 & 301 & \\
\hline Upper L. Constance & $\begin{array}{l}1980 \\
1981 \\
1982 \\
1983 \\
1984 \\
1985 \\
1986 \\
1987 \\
1988 \\
1989 \\
1990\end{array}$ & $\begin{array}{l}250 \\
250 \\
250 \\
250 \\
250 \\
250 \\
250 \\
250 \\
250 \\
250 \\
250\end{array}$ & $\begin{array}{l}? \\
? \\
? \\
? \\
? \\
? \\
? \\
? \\
? \\
? \\
?\end{array}$ & $\begin{array}{r}13 \\
37 \\
213 \\
42 \\
917 \\
367 \\
88 \\
23 \\
25 \\
2654 \\
2082\end{array}$ & $\begin{array}{l}\text { Quoss (in litt.) } \\
\text { Quoss (in litt.) } \\
\text { Quoss (in litt.) } \\
\text { Quoss (in litt.) } \\
\text { Quoss (in litt.) } \\
\text { Quoss (in litt.) } \\
\text { Quoss (in litt.) } \\
\text { Quoss (in litt.) } \\
\text { Quoss (in litt.) } \\
\text { Quoss (in litt.) } \\
\text { Quoss (in litt.) }\end{array}$ \\
\hline Lower L. Constance & $\begin{array}{l}1982 \\
1984 \\
1990\end{array}$ & $\begin{array}{l}2-15 \\
6-16 \\
1-20\end{array}$ & $\begin{array}{r}10 \\
9 \\
6\end{array}$ & $\begin{array}{r}117 \\
44 \\
385\end{array}$ & $\begin{array}{l}\text { Quoss (in litt.) } \\
\text { Quoss (in litt.) }\end{array}$ \\
\hline L. Neuchâtel & 1990 & $59-101$ & 5 & 63 & \\
\hline L. Lucerne & 1990 & $18-135$ & 6 & 275 & \\
\hline Upper L. Zurich & 1990 & $7.5-42$ & 4 & 104 & \\
\hline Lower L. Zurich & 1990 & $17-25$ & 4 & 29 & \\
\hline L. Thun & $\begin{array}{l}1973 \\
1990\end{array}$ & $\begin{array}{l}0.5-5 \\
0.4-58\end{array}$ & $\begin{array}{c}? \\
8+S^{*}\end{array}$ & $\begin{array}{r}\infty \\
1108\end{array}$ & Rufli (1975) \\
\hline L. Biel & $\begin{array}{l}1973 \\
1990\end{array}$ & $\begin{array}{l}3-35 \\
3-28\end{array}$ & $\begin{array}{l}? \\
7\end{array}$ & $\begin{array}{r}\infty \\
779\end{array}$ & Rufli (1975) \\
\hline L. Zug & $\begin{array}{l}1989 \\
1990\end{array}$ & $\begin{array}{r}15-32 \\
1-28\end{array}$ & $\begin{array}{l}6 \\
6\end{array}$ & $\begin{array}{r}519 \\
80\end{array}$ & \\
\hline L. Walenstadt & 1990 & $10-130$ & 5 & 114 & \\
\hline L. Sempach & $\begin{array}{l}1988 \\
1989 \\
1990\end{array}$ & $\begin{array}{l}1-50 \\
1-15 \\
1-15\end{array}$ & $\begin{array}{c}5+S^{*} \\
6+S^{*} \\
S^{*}\end{array}$ & $\begin{array}{l}\infty \\
\infty \\
\infty\end{array}$ & $\begin{array}{l}\text { A. Ventling (pers. com.) } \\
\text { A. Ventling (Pers. com.) } \\
\text { A. Ventling (pers. com.) }\end{array}$ \\
\hline L. Hallwil & $\begin{array}{l}1988 \\
1989 \\
1990\end{array}$ & $\begin{array}{r}10-20 \\
10-20 \\
1.5-24\end{array}$ & $\begin{array}{l}5 \\
5 \\
4\end{array}$ & $\begin{array}{l}384 \\
237 \\
621\end{array}$ & \\
\hline L. Joux & 1983 & $3-7$ & $\mathrm{~S}^{*}$ & 209 & Büttiker (1986) \\
\hline L. Sarnen & $\begin{array}{l}1982 \\
1983 \\
1984 \\
1985 \\
1990\end{array}$ & $\begin{array}{l}1-49 \\
1-49 \\
1-49 \\
1-49 \\
1-42\end{array}$ & $\begin{array}{c}6+\mathrm{S}^{*} \\
5+\mathrm{S}^{*} \\
5 \\
5 \\
4\end{array}$ & $\begin{array}{r}139 \\
54 \\
179 \\
70 \\
138\end{array}$ & \\
\hline
\end{tabular}

${ }^{*} \mathrm{~S}=$ sampling by diving and/or suction apparatus. 


\section{Results and discussion}

Results on the relationship between in situ embryogenesis and trophic state are summarized in Fig. 1. Egg data are means of all dredging hauls per year taken in a particular lake. The data roughly fall into three groups delimited by broken lines in Fig. 1:

a) In eutrophic lakes $\left(\mathrm{PO}_{4}-\mathrm{P}\right.$ and $\mathrm{P}_{\text {tot }}$ concentrations $>80$ and $90 \mathrm{mg} \mathrm{m}^{-3}$, respectively), eggs do not develop up to hatching. Lake Biel does not fit into this scheme, a fact which might be attributed to the large flushing rate, causing a significant export of autochthonous organic matter. Thus, sediment quality might not fully reflect the trophic state of this lake.

b) In lakes with phosphate and total phosphorus concentrations between about 35-40 and 80$90 \mathrm{mg} \mathrm{m}^{-3}$, respectively, embryonic development exhibits large fluctuations, ranging from zero to $80 \%$ viable eggs.

c) In mesotrophic to oligotrophic lakes $\left(\mathrm{PO}_{4}-\mathrm{P}\right.$ and $P_{\text {tot }}$ concentrations $\leq 35$ and $40 \mathrm{mg} \mathrm{m}^{-3}$, respectively), eggs develop normally at about $10 \%$ to almost $100 \%$. The extremely high pro- portion of viable eggs found in Lake Thun points to ideal incubation conditions in a clean gravel bottom along parts of the shore. Low values reflect either unfavourable conditions in certain years, or are due to sampling on muddy patches of otherwise more favourable sediments (Downing \& Rath, 1988).

Again, a comparison of these results with the oxygen profiles in winter does not explain the varying degree of impairment of in situ embryogenesis. At the onset of spawning, oxygen concentration is always higher than $7 \mathrm{mg} \mathrm{l}^{-1}$ (Lake Hallwil in 1989/90: $4.5 \mathrm{mg} \mathrm{l}^{-1}$ ) at the depth of the spawning grounds. A different explanation for egg mortality had therefore to be found, and the following model, supported by evidence from the literature, was developed (see Fig. 2).

Normal in situ development of whitefish eggs depends, among other factors, on adequate oxygen supply, and on the absence of toxic substances in the diffusive boundary at the sedimentwater interface where the eggs are situated. The steepness of the oxygen gradient in the diffusive boundary layer and, thus, the presence or absence of oxygen on the sediment surface are controlled
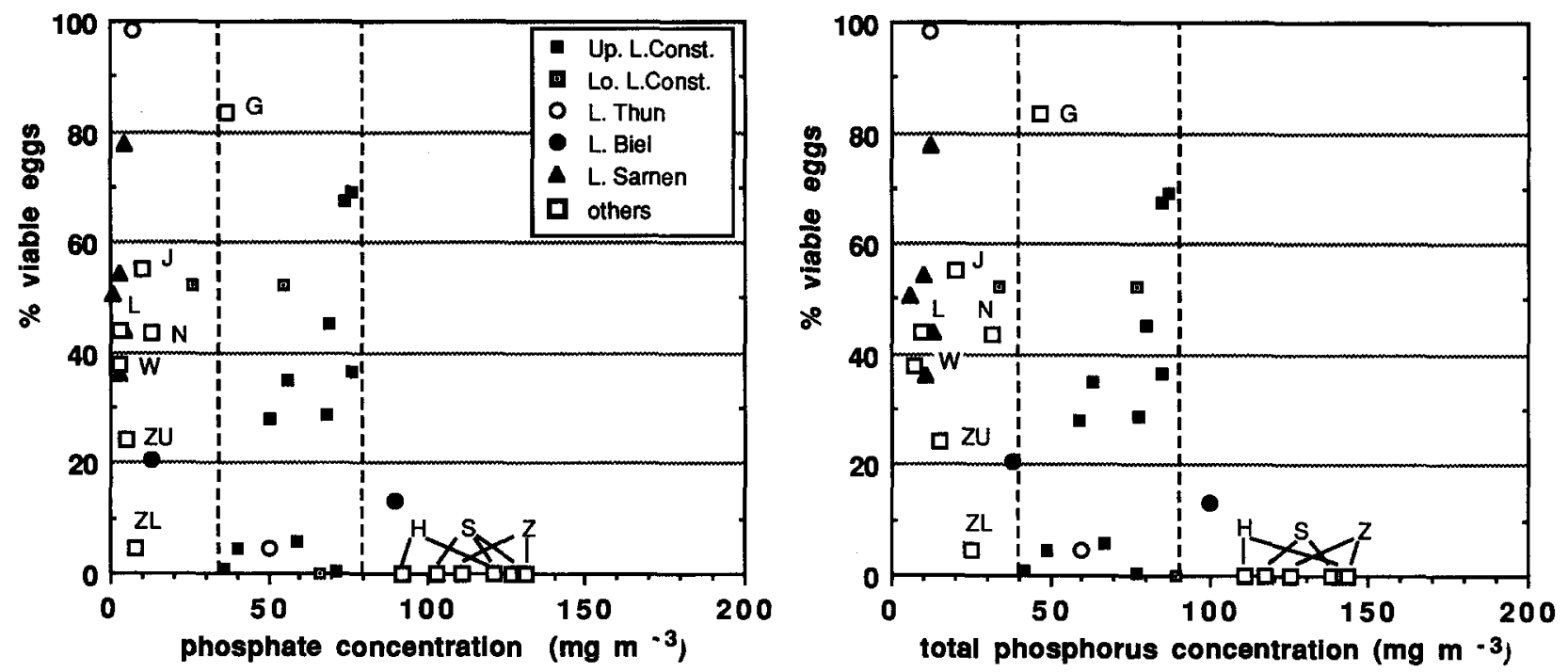

Fig. 1. Relationship between trophic state (spring phosphorus concentration) of 15 Swiss lakes, and the proportion of viable whitefish eggs found prior to hatching. Phosphorus concentration as soluble reactive phosphorus (phosphate, left) and total phosphorus (right). Lake abbreviations: G Geneva, H Hallwil, J Joux, L Lucerne, N Neuchâtel, S Sempach, W. Walenstadt, Z Zug, ZL Lower L. Zurich, ZU Upper L. Zurich. For broken lines see text. 


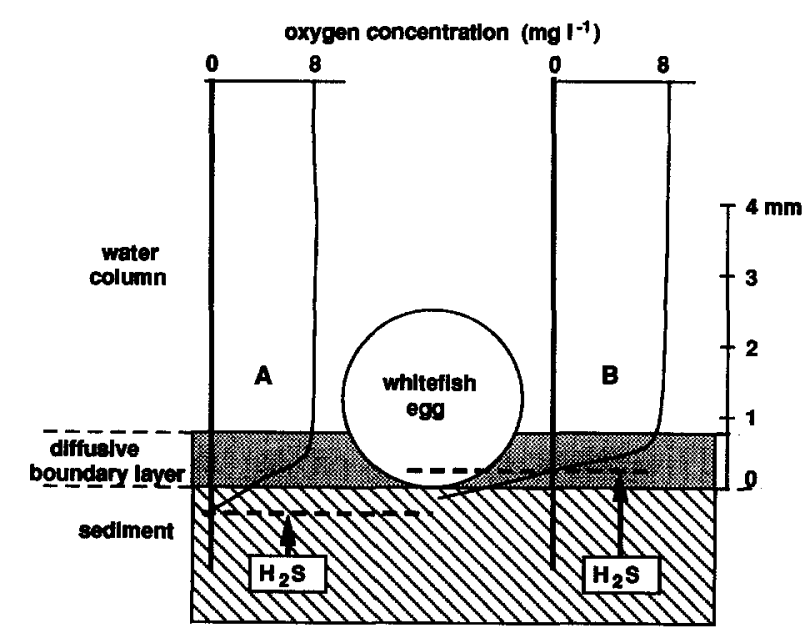

Fig. 2. Schematic diagram explaining the possible cause of egg mortality on the sediment of a eutrophic lake (B): High oxygen uptake of the sediment renders the sediment surface almost anoxic, allowing hydrogen sulfide to diffuse from the sediment into the egg. Low oxygen uptake in oligotrophic lakes (A) results in a well oxygenated sediment surface.

by the oxygen uptake of the sediment (Jørgensen \& Revsbech, 1985). Oxygen uptake, in turn, depends on the amount of organic matter deposited on the sediment each year through sedimentation. Sedimentation rates of organic matter are directly correlated with primary production (Bloesch \& Uehlinger, 1990) which is the closest measure of trophic state. Consequently, in eutrophic lakes, the oxygen gradient in the diffusive boundary layer is expected to be significantly steeper than in oligotrophic lakes, reaching the anoxic state already above the sediment surface (Fig. 2). In oligotrophic lakes with low oxygen uptake by the sediment, sediment surfaces are most likely to be oxic, allowing fish eggs to develop normally. Since the diffusive boundary layer is about $0.2-1 \mathrm{~mm}$ thick (Jørgensen \& Revsbech, 1985), parts of a whitefish egg (diameter $2.0-2.8 \mathrm{~mm}$ ) are exposed to an anoxic environment in eutrophic lakes. Possible causes of egg mortality, apart from hypoxia, are the diffusion of toxic metabolic compounds $\left(\mathrm{H}_{2} \mathrm{~S}, \mathrm{CH}_{4}\right)$ from the sediment into the developing egg.

Natural reproduction of salmonids other than whitefish may also be impaired by eutrophication.
Arctic charr (Salvelinus alpinus L.) often coexists in lakes with whitefish and is of particular interest because it is a native fish species of high commercial value and ecological significance. It spawns on gravel beds at depths of $25-90 \mathrm{~m}$ (Ruhlé, 1977; Rubin, 1990). The eggs sink into the spaces between the stones where they are fairly well protected against predation, but where water circulation is minimal and sedimentation high. Rubin (1990) found a strong dependence of embryonic mortality on oxygen concentration $10 \mathrm{~cm}$ above the substrate: oxygen concentrations of $8.7-9.2 \mathrm{mg} \mathrm{l}^{-1}$ were associated with $63-97 \%$ mortality while the lowest mortality $(53 \%)$ was found at the highest oxygen level $\left(10.4 \mathrm{mg} \mathrm{l}^{-1}\right)$. The high proportion of hatchery-bred charr in the catch of the Lake Geneva fishery (Champigneulle et al., 1988) indicates poor natural reproduction in this meso-eutrophic lake. The difficulty in assessing charr reproduction lies in the fact that charr eggs usually cannot be sampled with the technique adopted for whitefish eggs. Successful embryonic development of charr in Lake Lucerne could nevertheless be proven by the accidental dredge catch of a yolk sac fry and two empty egg shells of charr (Meng \& Müller, 1988). Sampling by SCUBA diving or from a submarine (B. Büttiker, pers. com.; Rubin, 1990) has been done in Lake Geneva, but is rather inefficient and too complicated for routine surveys in a larger number of lakes. At this time it is hypothesized that successful in situ embryogenesis of charr would require equally low or even lower trophic states as compared to that of whitefish.

\section{Conclusions}

Total mortality of whitefish eggs in eutrophic lakes with high oxygen concentrations in the water column above the sediment shows that natural reproduction cannot be restored by trying to increase hypolimnetic oxygen concentration through artificial oxygenation. Instead, oxygen uptake of the sediment has to be lowered by reducing primary production or phosphorus concentration in the lake. This is in agreement with 
pertinent conclusions from lake restoration studies (Gächter, 1987).

The large variation in the proportion of viable eggs in oligotrophic and mesotrophic lakes reflects the fact that there is no simple linear relationship between spring phosphorus concentration and quality of the sediment. Sediment patchiness (Downing \& Rath, 1988) adds further variation to the results of egg surveys. In order to test the mortality mechanism proposed above, a parameter more closely related to oxygen consumption of the sediment, such as total organic carbon, will be measured on the whitefish spawning sites during future egg surveys. This parameter not only refers to autochthonous organic matter, but also integrates allochthonous matter which is independent of trophic state and which may introduce additional variation in the relationship between trophic state and egg development.

Finally, the results of this study demonstrate that the aims of lake restoration as defined by the Swiss water quality standards are not in conflict with the aims defined from a fish ecology point of view. Contrary to earlier belief, the aim regarding phosphorus concentration and primary production is more important than the oxygen standard for restoring natural reproduction of salmonid fish. Oxygen concentration is usually sufficient for successful reproduction when trophic state is low. This should be borne in mind when internal measures are envisaged for restoring a eutrophic lake inhabited by coregonids and charr.

\section{Acknowledgements}

I thank the fisheries agencies of Cantons Zurich, Bern, Luzern, Obwalden, Zug, Aargau, Thurgau and Vaud for permission to sample eggs, and the fish wardens of these agencies for support with field work. All sampling data from Upper Lake Constance, and partly from Lower Lake Constance were kindly made available by $\mathrm{H}$. Quoss, Institut für Seenforschung und Fischereiwesen, Langenargen. The water protection agencies of Cantons Zurich, Bern, Zug, Vaud and Neuchâtel supplied physical and chemical data on lakes.
The assistance of B. Germann, C. Grieder, M. Mbwenemo-Bia, M. Stoll, A. Ventling and M. Zeh in sampling and sample processing is greatly acknowledged. J. Bloesch and $\mathrm{H}$. Bührer provided lake data, literature and helpful discussions.

\section{References}

Ambühl, H., 1987. Seenrestaurierung in Theorie und Praxis: Eine Aufgabe des modernen Gewässerschutzes. GasWasser-Abwasser 67: 433-438.

Bloesch, J. \& U. Uehlinger, 1990. Epilimnetic carbon flux and turnover of different particle size classes in oligo-mesotrophic Lake Lucerne, Switzerland. Arch. Hydrobiol. 118: 403-419.

Büttiker, B., 1986. In situ observations on coregonid eggs survival in Lake Joux (Switzerland). Arch. Hydrobiol. Beih. 22: 353-361.

Champigneulle, A., M. Michoud, D. Gerdeaux, C. Gillet, J. Guillard \& R. Rojas-Beltan, 1988. Suivi des pêches de géniteurs d'omble chevalier (Salvelinus alpinus L.) sur la partie française du Lac Léman de 1982 à 1987. Premières données sur le pacage lacustre de l'omble. Bull. Fr. Pêche Piscic. 310: 85-100.

Downing, J. A. \& L. C. Rath, 1988. Spatial patchiness in the lacustrine sedimentary environment. Limnol. Oceanogr. 33: 447-458.

Elster, H.-J., 1933. Eine Schlitten-Dredge. Int. Revue ges. Hydrobiol. Hydrogr. 29: 290-292.

Fricker, H. J., 1980. OECD eutrophication programme. Regional project: Alpine lakes. Swiss Federal Board for Environmental Protection, Bern, 233 pp.

Gächter, R., 1987. Lake Restoration. Why oxygenation and artificial mixing cannot substitute for a decrease in the external phosphorus loading. Schweiz. Z. Hydrol. 49: 170185.

Jørgensen, B. B.\& N. P. Revsbech, 1985. Diffusive boundary layers and the oxygen uptake of sediments and detritus. Limnol. Oceanogr. 30: 111-122.

Lahti, E., 1979. On the factors affecting the survival of the eggs of vendace (Coregonus albula) in different lake types. Third Congressus Europaeus Ichthyologorum (manuscript), Warszawa, 18-25 Sept. 1979, 4 pp.

Luczynski, M. \& A. Kirklewska, 1984. Dependence of Coregonus albula embryogenesis rate on the incubation temperature. Aquaculture 42: 43-55.

Meng, H. J. \& R. Müller, 1988. Assessment of the functioning of a whitefish (Coregonus sp.) and char (Salvelinus alpinus L.) spawning ground modified by gravel extraction. Finnish Fish. Res. 9: 477-484.

Nümann, W. \& H. Quoss, 1972. Strudelwürmer dezimieren den Felchenlaich. - Ursachen für die unterschiedlichen Fangerträge in der Blaufelchen-Fischerei des Bodensees. Fischwirt 22: 25-27. 
Rubin, J.-F., 1990. Biologie de l'omble chevalier, Salvelinus alpinus (L.), dans le Léman (Suisse). Doctoral thesis, Univ. Lausanne, Fac. Sciences, Lausanne, 169 pp.

Rufli, H., 1975. Biologie der Coregonen im Thuner- und Bielersee. Doctoral thesis 5451, Swiss Federal Polytechnical Institute (ETH), Zürich, $178 \mathrm{pp.}$

Ruhlé, Ch., 1977. Biologie und Bewirtschaftung des Seesaiblings (Salvelinus alpinus L.) im Zugersee. Schweiz. Z. Hydrol. 39: 12-45.

Steinmann, P., 1950. Monographie der schweizerischen Koregonen. Schweiz. Z. Hydrol. 12: 340-491.

Ventling-Schwank, A. \& R. Müller, 1991. Survival of core- gonid (Coregonus sp.) eggs in Lake Sempach, Switzerland. Verh. int. Ver. Limnol. 24: 2451-2454.

Vollenweider, 1968. Scientific fundamentals of the eutrophication of lakes and flowing waters, with particular reference to nitrogen and phosphorus as factors in eutrophication. The Organization for Economic Cooperation and Development (OECD), Paris, 264 pp.

Wilkonska, H. \& H. Zuromska, 1981. Effect of environmental factors and egg quality on the mortality of spawn in Coregonus albula (L.) and Coregonus lavaretus (L.). Pol. Arch. Hydrobiol. 29: 123-157. 